\title{
PRIVILEGE IN DISCOVERY OF DOCUMENTS
}

\author{
JOHN N. CRAIG*
}

\section{INTRODUCTION}

The purpose of this note is to explore the use of "privilege" in the context of an Affidavit of Documents. To facilitate this, a brief review of the procedure for the discovery of documents under the Alberta Rules of Court is set out; a working definition of privilege in the context of these rules is established; the different types of privilege are discussed; and the effect of privilege, once it has been properly claimed, is briefly noted. A discussion of the manner and effect of waiving privilege conclude this paper.

This note will also show that Alberta Courts are following the current Canadian trend of restricting privilege and broadening the circumstances in which it can be waived, in order to encourage full disclosure of all material evidence. Their reasoning appears to be that full disclosure will result in a quicker and fairer determination of any given action.

\section{DISCOVERY OF DOCUMENTS}

In part 13 of the Rules of Court the general procedure for discovery is set out. R's 186-199 establish the procedure for the discovery of documents. Under R 186(2), after pleadings have been closed, a party by notice in writing can require an adverse party to set out in the form of an affidavit all documents he has or had, which relate to the action. $R$ 188(a) requires the adverse party to list these documents in the affidavit. $R$ 188(b) allows the adverse party to set out in the affidavit any documents he objects to producing and his grounds of objection. ${ }^{1}$ Although not explicitly mentioned, privilege can be one of the grounds used to object to the production of documents. This can be implied as R 194(2) allows the court to inspect any document to determine if it is in fact privileged. ${ }^{2}$ If the court determines a document is not privileged it will be discoverable despite the objection of the party. It is therefore important to determine the requirements necessary to establish and maintain a claim of privilege.

- Graduate, University of Alberta, Faculty of Law 1985.

1. Note an interesting hole in $R 195$ (2). If a party comes into possession of documents after he has originally filed his affidavit he is required upon request to supply the other party with a copy of the documents. There is no provision made for objection in such cases! The court may be forced to rely on R 4 and provide for the right to object by analogy to $R \quad 188(\mathrm{~b})$. Perhaps a clarifying ammendment is in order?

2. This changes the common law where statements made in the affidavit were conclusive with regard to grounds stated in support of privilege. (see Williston, W.B. and Rolls, R.J.; The Law of Civil Procedure (1970) 906.) This meant the judge could not review the grounds or examine the document and the other party could not cross-examine on the grounds of privilege. (see Birmingham \& Midland v. London \& Northwestern [1913] 3 K.B. 850; Bewicke v. Graham (1881) 7 Q.B.D. 400.) Both examination by the judge (R 194 (2)) and cross-examination upon the affidavit ( $194(3)$ ) are now allowed. 


\section{PRIVILEGE GENERALLY}

The general rule in the course of any action is that all the evidence possessed by any party is discoverable by the other party. The rationale for this rule is that disclosure assists the parties and the court to discover the truth and thus ensures that claims are not improperly or unnecessarily brought and that justice is done.

Privilege developed as an exception to this rule. The rationale for allowing privilege as an exception may vary, depending on the type of privilege claimed. Privilege in its simplest form therefore, is merely a right to refuse to disclose evidence which otherwise would have to be disclosed. In the context of documents, this means a party is not required to produce a "privileged" document for his adversary's inspection.

\section{TYPES OF PRIVILEGE ${ }^{3}$}

\section{A. SOLICITOR - CLIENT COMMUNICATIONS}

In the context of documents these communications take the form of letters, interview notes, memo's etc. The requirements which must be met to claim this type of privilege are set out by Wigmore: ${ }^{4}$

1. The communications must originate in a confidence that they will not be disclosed.

2. This element of confidentiality must be essential to the full and satisfactory maintenance of the relation between the parties.

3. The relation must be one which in the opinion of the community ought to be sedulously fostered.

4. The injury that would inure to the relation by the disclosure of the communications must be greater than the benefit thereby gained for the correct disposal of litigation.

It is implicit in these requirements that there be an intention on the part of the party initially disclosing the information to make it privileged. ${ }^{5}$ This privilege extends to notes taken during interviews even before the solicitor is formally retained. The rationale for excepting these communications from the general discovery rule is inherent in the requirements which must be met. It is based on the need to allow a client to confer fully and frankly with his solicitor to ensure he is properly represented by skilled counsel. It also ensures that portions of his evidence are not used by the other party out of context before they are properly presented by counsel.

3. A thorough discussion of each of the types of privilege would unduly extend the length of this paper without furthering the conclusion reached. For this reason solicitor-client privilege, "lawyers brief" privilege and documents made in "anticipation of litigation" privilege are emphasized as they are the most common types claimed in practice and are most helpful in tracing current trends. The other types of privilege are lumped together and briefly discussed. Note also that "lawyer's brief" and "contemplation of litigation" privilege are included although there is an argument that they are not in fact privileges, but merely areas governed by rules of evidence which exclude them. (see Nova v. Guelph Engineering (1984) 42 C.P.C. 194 (Alta. C.A.)).

4. Wigmore on Evidence, 3rd ed. (1961) McNaughton Revision, Vol. 8 para 2285. Although an attempt was made to make those requirements a universal test for all types of privilege. (Strass v. Goldsack (1975) 58 D.L.R. (3d) 397 (Alta. Q.B.); D.C. McDonald J. (ad hoc)) this was rejected (Nova v. Guelph Eng. supra n. 3 - declaring MacDonald's comments obiter.).

5. Sopinka, J. and Lederman, S.N.; The Law of Evidence (1974) 166. 
Although other communications made in some particular relationships other than solicitor-client have been considered as privileged, (i.e. husband-wife) until relatively recently the courts have now shown an inclination to extend this privilege to other relationships (i.e. doctorpatient). There are however recent indications that the courts may be willing to extend this privilege to other relationships if Wigmore's four requirements are met. ${ }^{6}$ The standards to be met under the third and fourth requirements appear to be very high and are seldom if ever met in the eyes of the court.

\section{B. “LAWYER'S BRIEF" RULE}

This rule states that notes and materials which a solicitor prepares for use in a case cannot be discovered. The rationale for this rule is that if discovery of these documents was allowed, lawyers would be inhibited from keeping proper written records and inefficiency and sloppiness would result. Another rationale is that if discovery was allowed these materials might be presented by the other party to the court in a manner other than that contemplated when they were prepared. ${ }^{7}$

\section{PRIVILEGE FOR DOCUMENTS PREPARED IN CONTEMPLATION OF LITIGATION.}

This privilege is a simple extension of the "lawyer's brief" rule. It is reasoned that if the lawyer's brief is privileged, then material which comes into existence in the course of preparing that brief should also be privileged. ${ }^{8}$

This is by far the most controversial and litigated type of privilege. It involves documents or statements made at the request of a party or his lawyer when litigation is "contemplated". Although historically this privilege was very wide in that it did not matter who made the document or statement, ${ }^{9}$ it now appears that whether or not a document is privileged will depend on who its maker is. ${ }^{10}$

\section{Documents Made by the Party in Contemplation of Litigation}

These documents will fall under the rubric of solicitor-client privilege and must meet Wigmore's 4 requirements as discussed above.

2. Documents Made by a Lawyer in Contemplation of Litigation

These documents will be protected by the "lawyer's brief" rule.

3. Documents or Statements Made by a Party at the Request of an Adverse Party

6. Strass v. Goldsack supra n. 4; see also S.N. Lederman's comment on Strass [1976] 54 Can. Bar Rev. 422.

7. Strass v. Goldsack supra n. 4; Susan Hosiery Ltd.v. M.N.R. [1969] 2 Ex. C.R. 27.

8. Westminster Airways Ltd.v. Kuiwait Oil Co. Ltd. [1950] 2 All E.R. 596 (C.A.).

9. Gillespie v. Wacowich [1932] 1 W.W.R. 916 (Alta. S.C. App. Div.); Bourbonnie v. Union Insurance(1959) 28 W.W.R. 455 (Alta. C.A.); Birmingham and Midland supra n. 2.

10. Novav. Guelph Eng. supra n. 3. 
This situation often arises. An example is the common situation of an insurer taking a statement from an insured regarding an accident. The insurer may later allege a breach of the policy and refuse to pay the claim, forcing the insured to sue him for recovery under the policy. ${ }^{11}$ As noted above, it was formerly irrelevant to the issue of privilege that this statement was made by the very party whom the litigation was against. So long as the statement had been made in contemplation of litigation, the insurer could claim privilege and refuse to allow the insured access to that statement!

The present position clearly is that privilege does not attach to a communication made by one litigant to another. ${ }^{12}$ The reason given for this position is that fairness dictates that the result of litigation should not depend on the ignorance of one party regarding a statement he has made and can no longer recall. A party should therefore be allowed access to his own statement. ${ }^{13}$ The boundaries of privilege in this area have thus been restricted to allow courts to more effectively mete out justice by allowing all parties to be properly appraised of the facts and evidence.

4. Documents Made by an Independant Third Party at the Request of a Litigating Party ${ }^{14}$

Formerly, documents prepared by independent third parties were classified as privileged if contemplation of litigation was at least a "substantial purpose" in their preparation. ${ }^{15}$ This was so even if the document was predominantly prepared for other reasons. However the Alberta Court of Appeal has recently rejected this "substantial purpose" test. ${ }^{16}$ Now documents must have been prepared predominantly for purposes of litigation or in contemplation of litigation before they will be classified as privileged. ${ }^{17}$

It is also important that the third party that prepares the document be "independant". If the third party is an employee or an officer of the party he can be examined directly under R. 200 regarding the information in the document despite the fact that the document itself is privileged! ${ }^{18}$

\section{OTHER TYPES OF PRIVILEGE}

The privileges hereinafter discussed arise much less in practice than those mentioned above, many of them overlapping with the "contemplation of litigation" privilege. For these reasons and for purposes of brevity they will be briefly discussed together. ${ }^{19}$

11. This situation may commonly arise under S 320 of the Insurance Act.

12. Strass v. Goldsack supra n. 4; approved on this point in Nova v. Guelph Eng. supra n. 3.

13. Id.

14. e.g. accident reports, medical reports, opinions by appraisers etc.

15. Sowa v. Alberta Power (1982) 19 Alta. L.R. 206 (Q.B.).

16. Nova v. Guelph Eng. supra n. 3; see also Waugh v. British R/wys. [1979] 2 All E.R. 1169 (H.L.).

17. They did not go so far as to adopt the Australian "sole purpose" test; see discussion Nova v. Guelph Eng. supra n. 3.

18. Anderson v. Bank of B.C. [1876] 2 Ch. D. 644; Raymond v. C.P. Ltd. (1976) 2 A.R. 93 (Alta. S.C.T.D.).

19. For a more thorough treatment see Williston and Rolls supra p.p. 914-941; C.E.D. (Western) (3rd) Vol. 11 A Title 49 50-100. 


\section{Documents of Title}

Formerly documents of title were not discoverable if they related solely to the adverse party's title and in no way supported the discovering party's title. ${ }^{20}$ This type of privilege is of little use in Alberta which operates under the Torrens system.

\section{Documents Relating Solely to Adverse Party's Case ${ }^{21}$}

Given the current trend of courts to restrict privilege, this type will probably no longer be recognized in Alberta. ${ }^{22}$ Allowing such documents to be discovered may also encourage settlement.

\section{Incriminating Documents}

Not only have these been held to be privileged but it has also been held that a party need not answer questions on cross-examination of his affidavit if the answers to those questions would tend to inciriminate him. ${ }^{23}$

\section{State Documents}

The Crown can claim privilege of documents to prevent injury to the public interest. ${ }^{24}$ This privilege has been restricted however to situations where the public interest would be harmed and does not extend to documents that would merely make the Crown liable to pay compensation or simply embarrass them..$^{25}$

\section{Documents in Aid of Settlement}

These documents are privileged if they are prepared during bona fide negotiations for settlement. ${ }^{26}$ The use or absence of the words "without prejudice" are not conclusive one way or the other. The rationale for allowing this privilege is to encourage settlements. If such communications were not classified as privileged, parties would be reluctant to negotiate a settlement for fear of being prejudiced at the trial if negotiations were unsuccessful.

\section{E. SUMMARY OF CIRCUMSTANCES IN WHICH PRIVILEGE WILL BE ALLOWED}

It is submitted that one can see a trend in most of the types of privilege discussed above. The trend is to shrink the boundaries and limit the cir-

20. Morris v. Edwards (1890) 15 A.C. 309.

21. O'Rourkev. Darbishire[1920] All E.R. I (H.L.).

22. It is not recognized in British Columbia; see Duncan v. Royal Bank [1971] 3 W.W.R. 311 (B.C.S.C.).

23. Campbell v. Woods [1926] 2 W.W.R. 99 (Alta. S.C.) - such evidence was held privileged despite the Evidence Acts. Quaere whether the result would be the same today in light of the trend toward restricting privilege? It may be the courts will require the party to produce documents and answer cross-examination for purposes of that litigation but not allow the evidence to be used for subsequent criminal proceedings; see Alberta Evidence Act ss. 2,6.

24. See Alberta Evidence Act s. 35; Proceedings Against the Crown Act (Alta.) S 11; Canada Evidence Act ss. 36.1 - 36.3; R.v. Mannix (1981) 126 D.L.R. (3d) 155.

25. Duncanv. Cammell Laird \& Co. [1942] A.C. 624 (H.L.)

26. In re Ramsey (1870) 7 Moo D.C. (N.S.) 263. 
cumstances in which an objection on the basis of privilege will be allowed. It is further submitted that this trend will carry over to all types of privilege as cases in each of these areas arise.

\section{EFFECT OF PRIVILEGE}

If a claim of privilege is successfully made the documents need not be produced for inspection under R 191. Privilege may also be claimed for a portion of a document. ${ }^{27}$ Any document "once privileged is always privileged" 28 unless the privilege is waived.

\section{WAIVER}

Privilege can be lost or forfeited if it is waived by the party entitled to claim it. This waiver can be of all or part of the document. ${ }^{29}$ There are two types of waiver.

\section{A. EXPRESS WAIVER}

Obviously if a party expressly waives his right to privilege it will be extinguished. The conditions which must be met to expressly waive are: ${ }^{30}$

a) the party must possess knowledge of the existence of the privilege he is foregoing;

b) the party must have a clear intention to waive the privilege.

From a practical point of view this type of waiver will rarely occur as a party who in the first instance claims privilege is unlikely to subsequently expressly waive that privilege. It is more likely that a party will be found to have impliedly waived his privilege.

\section{B. IMPLIED WAIVER}

Wigmore ${ }^{31}$ states implied waiver can occur in one of two ways:

1) Conduct that indicates a plain intention to abandon privilege, or

2) circumstances or conduct which render it unfair and inconsistent to permit the retention of the privilege regardless of intention.

Wigmore's first rule is self-explanatory, being merely a variation of express waiver. Wigmore's second rule is interesting and merits further comment. Generally it is no longer fair for a party to claim privilege for a document when he himself has violated that privilege. Privilege can be violated either, by allowing the information contained in the document to come into the hands of another party; or, by the party who is claiming privilege attempting to use it as a "sword as well as a shield." 32 Some examples will help to illustrate. These examples will also illustrate that the courts have shown an increased tendency to broaden the circumstances in

27. Lazin v. Ciba-Geigy Canada Ltd. [1976] 3 W.W.R. 460 (Alta. S.C. App. Div.).

28. Bullock v. Corry [1877-78] 3 Q.B.D., 356; Strassv. Goldsack supra n. 4.

29. Trotterv. Cattan (1977) 3 C.P.C. 159 (Ont. Master).

30. Western Canadian Inv. Co. Ltd. v. McDiormid [1922] 1 W.W.R. 257 at 261 (Sask. C.A.); cited in Sopinka \& Lederman supra n. 5, p 182.

31. Wigmore on Evidence supra $\$ 2388$ (3).

32. Id.; this expression used by Wigmore expresses very well the effect of an attempt by the party to use the information contained in the document to further his own case and yet at the same time deny the other party access to the information. 
which waiver will be said to have occurred. Given that the standard for implied waiver in Wigmore's rules is fairness, and the fact that courts are currently expanding full disclosure and restricting privilege, it follows that courts will, in cases of doubt, find it "fair" in a wider range of circumstances that privilege be waived.

\section{Documents Examined by a Third Party}

If a party allows a privileged document to be examined by anyone else, privilege will be held to have been waived. It appears this result will occur even if the party allows the examination as a result of inadvertance or fraud. ${ }^{33}$

\section{Introducing the Document at Trial}

Introducing a privileged document into evidence is a classic example of a party attempting to use privilege as both a sword and a shield, and the privilege will be held to have been waived for purposes of subsequent legal proceedings. ${ }^{34}$

\section{Using a Document to Refresh Memory at Trial}

This is much the same as using the document at trial and a waiver can be implied on the same basis. ${ }^{35}$ Alternatively the court may find no privilege existed in the first place, as the document was not made with the intention it be privileged, but rather with the intention that it would be divulged. ${ }^{36}$

4. Making a Privileged Document the Basis of an Affidavit on a Motion

This allows the other party to cross-examine on the affidavit regarding questions of credibility, grounds and sources of the document. ${ }^{37}$ Waiver will be implied in this situation because it is unfair to allow a party to rely on a document to support his motion and yet not allow the adverse party to cross-examine on it.

5. Party Making Reference to Information in a Privileged Document on Direct or Cross-Examination

33. Delap v. C.P.R. (1914) S O.W.N. 667 (Chambers); Calcraft v. Guest [1898] 1 Q.B. 759.

34. Frind v. Sheppard [1940] O.W.N. 135.

35. Trotterv. Cattan supra n. 29.

36. James v. Maloney [1973] 15 O.R. 656; but note, though this element of Wigmore's requirements needs to be met for purposes of solicitor-client privilege it may be that the document is made in contemplation of litigation which arises independent of intention. It is better therefore to rely on the waiver analysis.

37. Warunkiv. Warunki(1983) 24 Alta. L.R. 266 (Q.B.); Trotterv. Cattan supra n. 29; James v. Maloney supra n. 36. 
On the basis of the same rationale noted in 4. above, in these circumstances the document should be produced for purposes of testing its credibility. There appears to be little authority on this point. ${ }^{38}$ In light of the current trend of the courts to make as much information as possible available to all parties it is submitted this sound proposition is likely to be readily accepted.

\section{CONCLUSION}

In civil litigation there are two competing principles at work. The first is that all relevant evidence should be made available to the court. The second is that some documents should remain confidential and privileged for reasons of social policy. ${ }^{39}$ The areas of privilege discussed above illustrate that the pendulum has swung toward disclosure of documents. While a party may still claim privilege, the circumstances in which it will be allowed have been circumscribed. Further, even though privilege may be granted, in keeping with this trend toward disclosure, courts will be more willing to find an implied waiver based on fairness.

38. See Smith v. Smith [1958] O.W.N. 135 (H.C.); McCormick on Evidence (2nd Ed. 1972) P. 195; Sopinka and Lederman supra 183. But see Trotter v. Cattan supra n. 29, summarily dismissing the idea that privilege can be lost by reference to a document during crossexamination.

39. Waugh v. British Rlwy supra n. 16; Sopinka and Lederman supra n. 5. 